\title{
Zulliger R-Optimized in the Evaluation of Depressive Characteristics
}

\author{
André Pereira Gonçalves ${ }^{1}$ \\ Anna Elisa de Villemor-Amaral ${ }^{1}$
}

\begin{abstract}
Depression is one of the most prevalent mental disorders in the world with more than 300 million diagnoses. Studies on the contributions that instruments offer in understanding the functioning of depressive patients are necessary. Therefore, our study aimed to compare the frequency of codes related to depression in Zulliger R-optimized application in a group of depressive individuals with non-clinical group. The study included 86 participants, 43 depressive patients and 43 non-clinical patients. The Escala Baptista de Depressão (EBADEP-A) was used to identify depressive symptoms in the clinical group and Zulliger was administered with R-optimized application. To compare the groups, the $t$-test and magnitude of differences (d) were used. The results showed differences between groups in the variables Mixed Determinants, Sum of achromatic color responses, pure color responses (C), Mor and AG. We understood that Zulliger R-optimized application may be useful in understanding the functioning of the depressive subject.
\end{abstract}

Keywords: depression, projective techniques, Zulliger Z test

\section{Zulliger R-Otimizado na Avaliação de Características Depressivas}

Resumo: A depressão é um dos transtornos mentais mais prevalentes no mundo com mais de 300 milhões de diagnósticos. Estudos sobre as contribuições que instrumentos oferecem na compreensão do funcionamento de pacientes depressivos são necessários. Este estudo teve por objetivo comparar a frequência dos códigos relacionados à depressão no Zulliger aplicação R-otimizado em um grupo de depressivos com grupo não clínico. O estudo contou com 86 participantes, 43 pacientes depressivos e 43 não clínico. Foi utilizada a Escala Baptista de Depressão (EBADEP-A) para rastrear sintomas depressivos no grupo clínico e o Zulliger foi administrado com aplicação R-otimizada. Para comparar os grupos foi utilizado o teste t e magnitude das diferenças (d). Os resultados demonstraram diferenças entre grupos nas variáveis Determinantes Mistos, Soma de respostas de cor acromática, respostas de cor pura (C), Mor e AG. Entende-se que Zulliger aplicação R-otimizado pode ser útil na compreensão do funcionamento do sujeito depressivo.

Palavras-chave: depressão, técnicas projetivas, teste de Zulliger

\section{Zulliger R-Optimizada en la Evaluación de las Características Depresivas}

Resumen: La depresión es uno de los trastornos mentales más frecuentes en el mundo y actualmente cuenta con más de 300 millones de diagnósticos. Se necesitan estudios sobre las contribuciones de los instrumentos para comprender el funcionamiento de los pacientes deprimidos. Este estudio tuvo como objetivo comparar la frecuencia de los códigos relacionados con la depresión en la aplicación R-optimizada en Zulliger entre un grupo de deprimidos y un grupo no clínico. En el estudio participaron 86 personas, de las cuales 43 eran pacientes deprimidos y 43 pacientes no clínicos. La Escala Baptista de Depresión (EBADEP-A) se usó para rastrear los síntomas depresivos en el grupo clínico y el Zulliger se administró con la aplicación R-optimizada. Se utilizaron la prueba t y la magnitud de las diferencias (d) en la comparación entre grupos. Los resultados apuntaron diferencias entre los grupos en las variables Determinantes mixtos, Suma de respuestas de color acromática, respuestas de color puro (C), Mor y AG. La aplicación R-optimizada en Zulliger puede ser útil para comprender el funcionamiento del sujeto deprimido.

Palabras clave: depresión, técnicas proyectivas, test de Zulliger

${ }^{1}$ Universidade São Francisco, Campinas-SP, Brazil

Support: This study was funded by the Coordination for the Improvement of Higher Education, Brazil (CAPES - Coordenação de Aperfeiçoamento de Pessoal de Nível Superior), funding code 001.

Correspondence address: André Pereira Gonçalves. Universidade São Francisco. Rua Waldemar César da Silveira, 105 - Vila Cura D’Ars (SWIFT), Campinas-SP, Brazil. CEP 13.045-510.E-mail: andregoncalvespsi@gmail.com
Depression is one of the most frequent mental disorders in the world. According to the World Health Organization (WHO, 2017), 300 million people are affected by this disorder. Among mental disorders, depression is the main cause of disability and responds to $12 \%$ of total absences from professional activities. It can be considered of multifactorial etiology; several variables 
should be evaluated as responsible for its onset, development and remission (Durisko, Mulsant, \& Andrews, 2015; Fried \& Nesse, 2015; Lichtenberg \& Belmaker, 2010).

The diagnosis of depression is mostly based on the Statistical Diagnostic Manual of Mental Disorders (DSM-5), which characterizes depression as clear changes in affection, cognition and neurovegetative functions, with interepisodic remissions. Diagnosis is made when the patient necessarily has anhedonia or depressed mood and four more symptoms among marked weight loss or gain, insomnia or hypersomnia, fatigue, psychomotor agitation or retardation, feeling of excessive or inadequate guiltlessness or guilt, impaired ability to think or concentrate, and recurrent thoughts of death. For the diagnosis, symptoms must be present for at least two weeks (American Psychiatric Association [APA], 2014).

In addition to the criteria listed in the DSM-5, clinical practice has offered perceptions of symptoms of depression other than the ones described by the DSM-5, which may be associated with the disorder. Some of these symptoms are anxiety, difficulty in maintaining relationships with confidence, social instability, irritability, hopelessness, social avoidance, ruminations about the past and anguish, among others. These symptoms may be important in diagnostic aid and differential diagnosis (Beard et al., 2016; Beck, Rush, Shaw, \& Emery, 1997; Lichtenberg \& Belmaker 2010).

Despite the well-defined diagnostic criteria in the DSM-5, the evaluation of people with depression is complex. The symptoms that characterize depression may be linked to other disorders of psychological/psychiatric origin such as anxiety, stress, Burnout syndrome, among others. Thus, a careful investigation is necessary to minimize the chances of a misdiagnosis and, consequently, less effective treatments (Baptista, 2012).

Goldberg (2011) exemplifies the complexity in the diagnosis of major depression based only on manuals such as DSM-5 or ICD-10. The author points out that a patient with psychomotor retardation, hypersomnia and weight gain has the same diagnosis as another with agitation, insomnia and weight loss, even displaying opposite symptoms. This questioning shows how sensitive is a proper diagnosis, which is consistent with the reality of the person. Therefore, some tests can contribute in different ways to the identification of depression.

An approach with the use of various techniques, such as observation, tests and interviews, could benefit screening by understanding the functioning of the depressive subject and identifying personality traits that may be related to depression. The multimethod evaluation provides the professional with several angles on the same problem, which allows a better understanding of the manifestation of the pathology and the general functioning of the subject and its singularities, providing the professional psychologist with more correct choices for the treatment of the patient (Mihura, 2012; Mihura \& Graceffo, 2014; Morey \& McCredie, 2019).

Based this perspective, studies are important to verify the contributions of the different instruments in the evaluation of people with depression. Zulliger is a projective method widely used in Brazil that can provide relevant information about the person's mental universe, constituting a tool capable of providing relevant information about the functioning of the depressive subject and the main personality traits that may be related to this psychopathology (Villemor-Amaral \& Machado, 2011; Villemor-Amaral \& Primi, 2009).

Zulliger is a test developed by Hans Zulliger in 1948, based on the Rorschach Inkblot test, but applied, coded and interpreted in a shorter time. It maintained the characteristics already consolidated in the Rorschach test, such as the use of stimuli in semi-structured and symmetric ink stains and the instructions for application and coding, but with lesser stimuli. Rorschach test contains ten cards with inkblots, whereas Zulliger has only three cards (Rivera Carpio \& Cubas Lugón, 2011; Vaz \& Alchieri, 2016; Villemor-Amaral \& Primi, 2009; Zulliger \& Salomon, 1970).

In Brazil, two coding and interpretation systems are available for use in Zulliger, the Klopfer System (Vaz \& Alchieri, 2016) and the Comprehensive System (VillemorAmaral \& Primi, 2009). The Comprehensive System (CS) was developed by Exner in the mid-1970s for the coding of Rorschach test. Therefore, studies were conducted for the use of the Comprehensive System in Zulliger due to their similarity (Brinkmann, 1998; Mahmood, 1990; Mattlar et al., 1990; Rivera Carpio \& Cubas Lugón, 2011; Zdunic, 1999).

The Manual of Zulliger Comprehensive System (ZCS) was published in Brazil in 2009 by Villemor-Amaral and Primi. Hence, several researches using the ZCS have been conducted (Franco \& Villemor-Amaral, 2012; Grazziotin \& Scortegagna, 2016a, 2016b; Villemor-Amaral \& Machado, 2011), including standardization studies with children.

The ZCS has two phases: response and clarification. Firstly, the rapport is performed with the subject and then the cards are shown along with the question "What does this look like?". The second phase aims to clarify where in the inkblot the person saw the answer given and what made it look like that. The correct and attentive application is essential for the psychologist to be able to code the answers with quality and obtain a more reliable evaluation of the subject (Villemor-Amaral \& Primi, 2009).

To recover studies that used Zulliger in the Comprehensive System for evaluation of depression, we searched for articles in the Journal Portal database of the Coordination for the Improvement of Higher Education Personnel (CAPES), Virtual Health Library (VHL) and Google Scholar in June (2018). The descriptors used were "Zulliger" and "Depression" in Portuguese and English. We did not delimited a time interval for the selection of articles, nor a specific approach or system for analysis of the test, because the intention was to cover as many productions as possible on this subject. This search allowed to find only two studies conducted in Brazil addressing Zulliger with patients with depression: Franco and VillemorAmaral (2012) and Villemor-Amaral and Machado (2011). We could not find international studies, which evidences a gap in publications on Zulliger and depression in general.

The research by Villemor-Amaral and Machado (2011) aimed to verify if the indicators of depression in the Rorschach test and in the Comprehensive System (SC) help in the evaluation of depression by Zulliger CS. The sample had 54 participants 
divided into a group of depressive individuals and a non-clinical group, with 27 participants each, all women. Depressive patients were diagnosed after psychiatric interviews and invited to participate based on medical records. The results of the FD $+\mathrm{V}$ indicators were significantly increased in the depressive group when compared with the non-clinical group, which corresponds to the introspection and, in the specific case of $\mathrm{V}$, a tendency to self-criticism that adds to the introspection accompanied by negative feelings about oneself. There was also a significant increase in the sum of shaded responses (SumSh); Egotism (EgoIndex); proportion between color responses $(\mathrm{CF}+\mathrm{C}<\mathrm{FC})$; Mixed Determinants (Blends) and Intellectualization (Intelect). The meaning of these indicators or their combinations are easily associated with the characteristics of depression described in the literature. Thus, the SumSh indicator concerns the experience of anxiety-related anguish, irritation, sadness, dysphoria; EgoIndex indicates the degree of self-concern and how much the person is focused on his/her own needs and concerns; $\mathrm{CF}+\mathrm{C}<\mathrm{HR}$ that may be related to excess control in the manifestation of feelings; Blends indicate flexibility of thought and the ability to perceive multiple facets of the same situation; Intelect refers to coping strategies by avoiding displeasing emotions. The authors concluded that Zulliger (in the Comprehensive System) can assist in the evaluation and understanding of the psychiatric functioning of patients with depression.

With a similar purpose of the previous research, Franco and Villemor-Amaral (2012) aimed to study the Zulliger and the Constellations of Rorschach in the Comprehensive System, including the Constellation of Depression (DEPI). The research included a sample of 141 Spanish companies. The sample was divided into two groups, non-patients, with 95 subjects and psychiatric patients with 46 , of which 18 participants were depressive according to the psychiatric diagnosis indicated in their protocols. The results showed that only the Abstract Content $(\mathrm{AB})$ indicator, which composes the intellectualization index $(2 \times A B+A R T+A Y)$, was significant $(p=0.015)$ with an increased mean in the sample composed of depressive patients when compared with the non-clinical sample. The authors concluded that it was not possible to predict depression using Zulliger, not ruling out the usefulness of the instrument to understand more specific aspects of depression in each patient.

Comparing the results of both studies, the different findings can be justified by the composition of the sample, so that, in the research conducted by Villemor-Amaral and Machado (2011), the sample was composed solely of women. Moreover, the treatment was performed in an outpatient clinic. In the study conducted by Franco and Villemor-Amaral (2012), the sample had a small number of participants diagnosed with depression and patients were in intensive care in psychiatric hospitals.

With an objective similar to the studies by Franco and Villemor-Amaral (2012) and Villemor-Amaral and Machado (2011), our study seeks to further verify if the codes and indicators of the Zulliger test (Table 1), similar to the Rorschach Methods related to depression in the literature (Exner \& Sendín, 1999; Franco \& Villemor-Amaral, 2012; Meyer, Viglione, Mihura, Erard, \& Erdberg, 2017; Mihura, Meyer, Dumitrascu, \& Bombel, 2013; Villemor-Amaral \& Machado, 2012; Villemor-Amaral \&
Primi, 2009), are more frequent in the depressive group when compared with the non-clinical group, changing, however, the test instructions, using the R-Optimized form adopted for Rorschach in the R-PAS system (Meyer et al., 2017).

The R-optimized application was designed for a new coding and interpretation system of Rorschach named Rorschach Performance Evaluation System (Meyer et al., 2017). This application aims to reduce the variability in the number of responses between protocols, avoiding that they be too short or long and affect the stability of the indicators. The response quantity range considered appropriate in Rorschach Method varies between 18 and 27 responses (Meyer et al., 2017; Viglione et al., 2015) and several studies were conducted to verify the usefulness of this type of application in Rorschach, finding satisfactory results that justify its use (Graceffo, Mihura, \& Meyer, 2014; Hosseininasab et al., 2019; Meyer et al., 2017, 2020; Shaffer, Erdberg, \& Haroian, 2007; Viglione et al., 2015). Based on the findings on the R-optimized application in Rorschach and considering that the low number of responses in Zulliger may hinder the results derived from this instrument, we inferred that personality traits related to depression could stand out more by forcing a greater number of responses.

Thus, to reduce the presence of very short protocols in the database, we opted for an application of the R-optimized type in Zulliger, to favor the stability and reliability of the results obtained with this instrument. Therefore, in addition to the instruction given when evaluating "What does this looks like?", it is also requested answers to three, four or five questions per card in order to obtain protocols with a minimum of nine and a maximum of 15 answers. Therefore, our study aimed to compare the frequency of codes related to depression in Zulliger R-optimized application in a group of depressive individuals with the non-clinical group.

\section{Method}

\section{Participants}

Our study included 86 subjects, divided into two groups: a group with 43 individuals with a diagnosis of depression and 43 non-clinical individuals. The group with diagnosis was mostly composed of women ( $88 \%$ ) and with age ranging from 18 to 62 years $(M=35.8$ and $S D=11.6)$, all under outpatient treatment with medical records that recorded recurrent ICD depression as their primary diagnosis (F33). They were under psychiatric follow-up, assisted at the Psychosocial Care Center (CAPS) and in the Family Health Strategy of a city in the state of Minas Gerais and in the Outpatient Clinic of the Hospital das Clínicas (AHC) of a city in the state of Paraná. As inclusion criteria, the participant should, in addition to the diagnosis of depression in the medical records, manifest depressive symptoms in the Baptist Depression Scale Adult (EBADEP-A), scoring more than 59 in this scale.

The non-clinical sample was extracted from a database previously collected by members of the Mental Health Psychological Assessment Laboratory (LAPSaM) at the 
Universidade São Francisco. We selected people without a history of depression or other psychiatric disorders in their report, who had never undergone neither psychiatric nor psychological treatment, and who did not use medication for any psychopathology. In total, the non-clinical sample had 43 subjects, aged between 19 and 65 years $(M=35.7$ and $S D=12.2)$ mostly women $(84.4 \%)$.

\section{Instruments}

Escala Baptista de Depressão - Adult (EBADEP-A). This scale was built to evaluate and identify depressive symptoms in the population. It is a self-applied instrument, that is, the participants read, interpret and mark the answer considered more compatible with their moment of life. The scale contains 45 items to be answered in a four-point Likert format. The validity, precision and standardization studies were conducted in two states (São Paulo and Minas Gerais), with a final sample of 1,676 participants. After studies of evidence of content validity, criterion and construct, in addition to precision, sensitivity, specificity and standardization, the scale brought good levels of reliability, validity and reliability. According to the Rasch model, the average infit and outfit adjustment indexes (1.05 and 1.06) were adequate; the scale allowed the discrimination of the different sample criterion groups; 0.95 reliability by Cronbach's alpha, in addition to a $77.5 \%$ sensitivity and $87.5 \%$ specificity. (Baptista, 2012).

Zulliger test. Composed of three cards with inkblots: one achromatic, one achromatic with insertion of red and one chromatic. The application consists of two consecutive phases: initially the cards are presented, one by one, and the subject is asked to answer the question "What does this looks like?"; in the second phase, the cards are shown again, this time for the subject to indicate what they look like and the location of the answers given in the first phase. The reliability studies of the test, through the test and re-test method and reliability among evaluators, indicated a value above 0.70 for agreement between judges and correlation above 0.60 of the first with the second application, indicating a high association (VillemorAmaral \& Primi, 2009). In our research, the participant was asked to provide three to five answers per card due to the proposal for controlling the number of responses (R).

Table 1 shows the depression-related codes selected for our study.

Table 1

Codes Related to Depression and their interpretations

\begin{tabular}{|c|c|}
\hline $\begin{array}{l}\text { Codes Related to } \\
\text { Depression }\end{array}$ & Interpretation of Codes \\
\hline $\mathrm{FD}+\mathrm{V}$ & Ability to perceive reality from different angles \\
\hline Mixed Determinants & Flexibility of thought and the ability to perceive multiple facets of the same situation \\
\hline $\begin{array}{l}\text { Sum of C' } \\
\left(\mathrm{FC}^{\prime}+\mathrm{C}^{\prime} \mathrm{F}+\mathrm{C}^{\prime}\right)\end{array}$ & $\begin{array}{l}\text { It may indicate attraction by lurid, negative, distressing stimuli, especially when it implies explanations or } \\
\text { descriptions of black or gray aspects. This score does not demonstrate precision in the relationship with } \\
\text { self-report or diagnosis of depression. }\end{array}$ \\
\hline Sum of $\mathrm{V}(\mathrm{FV}+\mathrm{VF}+\mathrm{V})$ & Related to processes of introspection and self-analysis, which may contain self-criticism and negative self-assessment \\
\hline Sum of $Y(F Y+Y F+Y)$ & $\begin{array}{l}\text { Anxious states related to stressful events and indicate affective tensions that alter normal functioning, which can } \\
\text { limit their ability to cope with conflicting and problematic situations }\end{array}$ \\
\hline Sum of $\mathrm{T}(\mathrm{FT}+\mathrm{TF}+\mathrm{T})$ & Affective needs related to the search for contact with other people \\
\hline Sum of $\mathrm{r}(\mathrm{rF}+. \mathrm{Fr})$ & Related to a poor process of personal maturity, besides being an element that hinders the balance of decision-making \\
\hline $\mathrm{C}$ & Affective discharges, emotion release with little or no cognitive modulation \\
\hline$(2)$ & Coupled with a more concrete and descriptive approach to stains \\
\hline $\mathrm{AB}$ & A greater tendency to intellectualization and to deny the effects of emotions on oneself \\
\hline COP & $\begin{array}{l}\text { Cooperation responses involve the ability or tendency to make and establish positive bonds, and their frequency } \\
\text { is scarce in depressive patients }\end{array}$ \\
\hline MOR & $\begin{array}{l}\text { Generally, when this code appears in a protocol, it can be assumed that the perception of the person's self-image } \\
\text { is devalued and with negative, damaged and dysphoric affections. The presence of high MOR tends to refer to } \\
\text { people with negative and pessimistic thinking, regarding the future and events in general }\end{array}$ \\
\hline AG & Violent behavior as well as a perception of oneself and others as something destructive \\
\hline Intellectualization & $\begin{array}{l}\text { Strategy of coping with emotions, which indicates people that tend to face the effects caused by emotions, } \\
\text { using cognitive processing }\end{array}$ \\
\hline Egotism & Degree of self-concern of a person and how much he is focused on his/her own issues \\
\hline Sum of Shaded & Difficulty in coping strategies, experience of anxiety-related distress, irritation, sadness, dysphoria \\
\hline Afr & Ability of the person to process more actively when exposed to affectively intense situations \\
\hline Isolation & People less involved in social interactions, with greater retraction in contact with others \\
\hline $\mathrm{S}$ & $\begin{array}{l}\text { Related to the search for independence and/or self-affirmation, which accentuates the most individual } \\
\text { components of the person }\end{array}$ \\
\hline
\end{tabular}




\section{Procedures}

Data collection. Data collection of the group with depression was approved by the Ethics Committee of the Universidade São Francisco. After approval, patients designated by these treatment centers that met the inclusion criteria were invited via telephone contact. All the participants signed an informed consent form after being informed of the procedures in our study.

Data were collected individually in a single session. The first instrument applied was the EBADEP-A to identify depressive symptoms. Only participants that presented depressive symptoms in EBADEP-A were selected for this study. Subsequently, the Zulliger Test was applied. In addition to the standard instructions of the Comprehensive System, the participant was asked to give three to five responses per card.

We used database modeling technique for the nonclinical group according to the model of other studies (Meyer et al., 2017), since the non-clinical group responded to Zulliger in the mode traditionally indicated by the CS, and not with R-optimized application. The protocols that contained between 9 and 15 responses were selected, since this is the expected interval in the R-optimized application, totaling 157 people. To provide an even more reliable comparison between the groups, they were paired by gender and age, totaling 43 subjects. We could not pair the groups by schooling due the absence of this information in the database of the non-clinical group.

Data analysis. For the statistical analysis, we used the Statistical Package for Social Sciences (SPSS), version 20.0I. Descriptive statistics were obtained for both groups.
Subsequently, for the comparison of depressive and nonclinical groups, the student $t$-test was used, being considered a significant difference when $p<0.05$. The magnitude of the difference was also evaluated using $d$ Cohen, calculated in an Excel spreadsheet and considered values above 0.30 .

\section{Ethical Considerations}

This study was approved by the Ethics Committee of the UniversidadeSãoFrancisco,(CAAE: 78320917.9.0000.5514; Opinion n. ${ }^{\circ}$ 2409144) and followed Resolution 466/12 of the National Health Council.

\section{Results}

Among the different codes present in the Zulliger Test, the means of responses of the non-clinical group with the clinical group were analyzed in variables similar to those of Rorschach test related to depression. The results indicated that there were significant differences between the groups, with increased values in depressive ones in the sum of achromatic responses $(\mathrm{FC}+\mathrm{C}$ ' $\mathrm{F}+\mathrm{C}$ '), pure color responses, i.e., no influence of form (C), morbid content (MOR), aggressive movement (AG). Table 2 shows that the Mixed Determinants were increased in the nonclinical group when compared with the depressive group.

Table 2 also shows the magnitudes of the differences between non-clinical and depressive groups, which ranged from 0 to 0.64 . The best variable to discriminate the groups were the Mixed Determinants $(d=0.64)$ and the worst variable for this purpose were the Texture $(\mathrm{T})$ responses that showed no difference $(d=0)$.

Table 2

Comparison between groups in the variables related to depression

\begin{tabular}{|c|c|c|c|c|c|c|}
\hline Variables & Diagnosis & $M$ & $D P$ & $t$ & $p$ & $d$ \\
\hline $\mathrm{FD}+\mathrm{V}$ & $\begin{array}{l}\text { Non-patient } \\
\text { Depressed }\end{array}$ & $\begin{array}{l}0.53 \\
0.35\end{array}$ & $\begin{array}{l}0.65 \\
0.79\end{array}$ & 1.186 & 0.239 & 0.25 \\
\hline Mixed Determinants & $\begin{array}{l}\text { Non-patient } \\
\text { Depressed }\end{array}$ & $\begin{array}{l}2.14 \\
1.21\end{array}$ & $\begin{array}{l}1.05 \\
1.78\end{array}$ & 2.94 & $0.004 * *$ & 0.64 \\
\hline $\mathrm{S}$ & $\begin{array}{l}\text { Non-patient } \\
\text { Depressed }\end{array}$ & $\begin{array}{l}2.14 \\
1.79\end{array}$ & $\begin{array}{l}1.61 \\
1.16\end{array}$ & 1.150 & 0.254 & 0.25 \\
\hline Sum of C' & $\begin{array}{l}\text { Non-patient } \\
\text { Depressed }\end{array}$ & $\begin{array}{l}1.00 \\
1.58\end{array}$ & $\begin{array}{l}1.13 \\
1.51\end{array}$ & 2.04 & $0.047^{*}$ & 0.43 \\
\hline Sum of V & $\begin{array}{l}\text { Non-patient } \\
\text { Depressed }\end{array}$ & $\begin{array}{l}0.16 \\
0.35\end{array}$ & $\begin{array}{l}0.37 \\
0.61\end{array}$ & 1.700 & 0.094 & 0.38 \\
\hline Sum of Y & $\begin{array}{l}\text { Non-patient } \\
\text { Depressed }\end{array}$ & $\begin{array}{l}0.74 \\
0.84\end{array}$ & $\begin{array}{l}0.79 \\
1.15\end{array}$ & 0.436 & 0.664 & 0.10 \\
\hline Sum of T & $\begin{array}{l}\text { Non-patient } \\
\text { Depressed }\end{array}$ & $\begin{array}{l}0.09 \\
0.09\end{array}$ & $\begin{array}{l}0.294 \\
0.366\end{array}$ & 0.00 & 1 & 0 \\
\hline Sum of $r$ & $\begin{array}{l}\text { Non-patient } \\
\text { Depressed }\end{array}$ & $\begin{array}{l}0.07 \\
0.05\end{array}$ & $\begin{array}{l}0.338 \\
0.231\end{array}$ & 0.382 & 0.704 & 0.07 \\
\hline $\mathrm{C}$ & $\begin{array}{l}\text { Non-patient } \\
\text { Depressed }\end{array}$ & $\begin{array}{l}0.02 \\
0.19\end{array}$ & $\begin{array}{l}0.152 \\
0.450\end{array}$ & 2.246 & $0.027 *$ & 0.51 \\
\hline
\end{tabular}


Continuation...

Table 2

Comparison between groups in the variables related to depression

\begin{tabular}{|c|c|c|c|c|c|c|}
\hline Variables & Diagnosis & $M$ & $D P$ & $t$ & $p$ & $d$ \\
\hline (2) & $\begin{array}{l}\text { Non-patient } \\
\text { Depressed }\end{array}$ & $\begin{array}{l}2.51 \\
2.26\end{array}$ & $\begin{array}{l}1.96 \\
1.51\end{array}$ & 0.676 & 0.501 & 0.14 \\
\hline $\mathrm{AB}$ & $\begin{array}{c}\text { Non-patient } \\
\text { Depressed }\end{array}$ & $\begin{array}{l}0.05 \\
0.12\end{array}$ & $\begin{array}{l}0.213 \\
0.448\end{array}$ & 0.933 & 0.359 & 0.20 \\
\hline $\mathrm{COP}$ & $\begin{array}{l}\text { Non-patient } \\
\text { Depressed }\end{array}$ & $\begin{array}{l}0.40 \\
0.33\end{array}$ & $\begin{array}{l}0.728 \\
0.522\end{array}$ & 0.511 & 0.611 & 0.11 \\
\hline MOR & $\begin{array}{l}\text { Non-patient } \\
\text { Depressed }\end{array}$ & $\begin{array}{l}0.35 \\
0.72\end{array}$ & $\begin{array}{c}0.573 \\
1.05\end{array}$ & 2.34 & $0.046^{*}$ & 0.47 \\
\hline $\mathrm{AG}$ & $\begin{array}{c}\text { Non-patient } \\
\text { Depressed }\end{array}$ & $\begin{array}{l}0.40 \\
0.91\end{array}$ & $\begin{array}{l}0.728 \\
0.921\end{array}$ & 2.857 & $0.005 * *$ & 0.61 \\
\hline Afr & $\begin{array}{l}\text { Non-patient } \\
\text { Depressed }\end{array}$ & $\begin{array}{l}0.57 \\
0.55\end{array}$ & $\begin{array}{l}0.193 \\
0.195\end{array}$ & 0.388 & 0.699 & 0.10 \\
\hline Isolation & $\begin{array}{c}\text { Non-patient } \\
\text { Depressed }\end{array}$ & $\begin{array}{l}0.16 \\
0.14\end{array}$ & $\begin{array}{l}0.143 \\
0.141\end{array}$ & 0.917 & 0.362 & 0.13 \\
\hline Egotism & $\begin{array}{l}\text { Non-patient } \\
\text { Depressed }\end{array}$ & $\begin{array}{l}0.23 \\
0.24\end{array}$ & $\begin{array}{l}0.165 \\
0.160\end{array}$ & 0.334 & 0.739 & 0.06 \\
\hline Intellectualization & $\begin{array}{l}\text { Non-patients } \\
\text { Depressed }\end{array}$ & $\begin{array}{l}0.46 \\
0.32\end{array}$ & $\begin{array}{l}0.700 \\
0.918\end{array}$ & 0.791 & 0.431 & 0.17 \\
\hline Sum of Shaded & $\begin{array}{l}\text { Non-patient } \\
\text { Depressed }\end{array}$ & $\begin{array}{l}2.19 \\
2.67\end{array}$ & $\begin{array}{l}1.89 \\
1.87\end{array}$ & 1.168 & 0.246 & 0.26 \\
\hline
\end{tabular}

Note. $M=$ mean; $S D=$ standard deviation.

\section{Discussion}

Psychological evaluation is a procedure that contributes to better understand the patient's functioning when well used. Among the possibilities of instruments and procedures, it is possible to use interviews, observations, objective and projective tests. A multimethod evaluation, with integration of various instruments and techniques, provides a broader and deeper view of the person, obtaining a view from different perspectives and providing a better understanding of the problem of each case (Mihura, 2012; Mihura \& Graceffo, 2014; Morey \& McCredie, 2019. Our study then sought to compare the frequency of codes related to depression in Zulliger in a clinical group of patients with depression and a non-clinical group. The variables were selected based on the literature of the area (Exner \& Sendín, 1999; Meyer et al., 2017; Mihura et al., 2013; Villemor-Amaral \& Machado, 2011; Villemor-Amaral \& Primi, 2009). The results suggest evidences that Zulliger is an instrument that can contribute to the understanding of depression-related personality traits within a multimethod evaluation process.

The Mixed Determinants showed a lower frequency in the protocols of the clinical group when compared with the non-clinical group, different from that found by VillemorAmaral and Machado (2011). This variable is associated with the flexibility of thought and the ability to perceive multiple facets of the same situation (Meyer et al., 2017), which can contribute to problem-coping strategies. This demonstrates that the non-clinical group tends to have more flexibility and richer perception of the facts, managing to divide its focus among the various possibilities of the environment, whereas the clinical group presents a more simplistic processing and difficulty in perceiving the different situations in a more complex way.

The sum of achromatic color codes (Soma C') increased in the clinical group. This code may be representative of the automatic attempt to contain the emotional expression of unpleasant affections, such as anguish and sadness, and also indicates that the subject is attracted by more negative and distressing stimuli (Exner \& Sendín, 1999; Villemor-Amaral \& Primi, 2009). The unpleasant affections, sadness and depressed mood, represented in Zulliger by C', are fundamental components for the diagnosis of depression according to the DSM-5 (APA, 2014). This result differs from the findings of Franco and Villemor-Amaral (2012), who did not find significant differences between the control group and patients in the achromatic color responses, contrary to the prediction. This possibly demonstrates that the R-optimized application mode in Zulliger and the consequent increase in responses per subject allowed the appearance of more indicators of depression than in previous studies, favoring the understanding of personality traits related to depressive symptomatology in Zulliger.

$\mathrm{C}$ responses may be related to affective discharges and emotion release with little or no cognitive modulation 
(Exner \& Sendín, 1999; Vaz \& Alchieri, 2016). This code increased in the clinical group when compared with the nonclinical group, which suggests that patients tend to have less cognitive control over the affects and manifest them more abruptly or intensely, such as excessive self-directed guilt, irritability and stress, placing the pure $\mathrm{C}$ responses in the Zulliger among the important codes for assessing the emotional dynamics of people with depression.

The MOR code indicates the presence of morbid contents, such as damaged objects, injured animals or humans, or attribution of feelings of pain or suffering to the identified objects. This indicator is usually increased in people with negative and pessimistic thinking about the future or the general events of everyday life (Exner \& Sendín, 1999). The findings of this study demonstrate an increase in MOR in the clinical group when compared with the non-clinical group, confirming the hypothesis that this variable may contribute to the diagnosis of depression or to indicate peculiarities. This had not happened in previous studies (Franco \& Villemor-Amaral, 2012; VillemorAmaral \& Machado, 2011) and at this moment, we can also assume that the data resulted from the modification of the test instructions and/or the sample increase, which also points to possible advantages of using an R-optimized application in the case of Zulliger.

The aggressive movement (AG) is a code that indicates a more destructive view of interpersonal relationships when increased (Villemor-Amaral \& Primi, 2009). This code may be related to a violent behavior, but not necessarily, and may represent a more negative or destructive conception of the person in the relationship with others (Exner \& Sendín, 1999; Meyer et al., 2017; Villemor-Amaral \& Primi, 2009). Aggressiveness, especially that which is not openly expressed, has been theoretically related to depression, as Melanie Klein posited about the depressive position (Klein, 1948); and pain and mourning depression are consequences of the fantasy of destruction of the object caused by aggressiveness. The results of our study are consistent with the results of research with Rorschach and reiterate the theoretical postulates.

The other codes in the literature on depression are $\mathrm{FD}+\mathrm{V}, \mathrm{S}, \mathrm{T}, \mathrm{V}, \mathrm{Y}, \mathrm{r},(2), \mathrm{AB}, \mathrm{COP}, \mathrm{Afr}$, Isolation Index, Egotism, Intellectualization and Shaded Determinants (Exner \& Sendín, 1999; Meyer et al., 2017; Mihura et al., 2013; Vaz \& Alchieri, 2016; Villemor-Amaral \& Primi, 2009), which did not present significant differences between the groups. Many codes are related to depression and, consequently, not all will necessarily be present in all cases, which is not only due to the idiosyncratic characteristics of people, but to the various forms of manifestation of this psychopathology, which is characterized by a wide set of symptoms (APA, 2014; Beard et al., 2016; Beck et al., 1997; Lichtenberg \& Belmaker, 2010). This is the reason why that multimethod evaluation is strongly recommended when understanding a person, helping them to understand themselves and, when applicable, guiding their treatment.
Based on these findings, we can conclude that the appearance of Blends, C' $\mathrm{C}, \mathrm{MOR}$ and $\mathrm{AG}$ is frequent in patients with depression; however, not necessarily or exclusively. The presence of high values of these indicators in Zulliger will then serve to alert the psychology professional to depression-related personality traits, which should be further investigated with the aid of other instruments. Furthermore, the behavior of these variables in each case and their combinations will allow a more refined analysis of how depression is manifested in a given individual.

In addition to the possible diagnostic indicators of psychopathological conditions using Zulliger, our research can contribute as an indicator of validity of the R-optimized application mode, since we evidenced the possibility of a more accurate view of the person or a group of people by a greater number of responses when comparing with the results of previous studies; thus bringing more confidence to the professional in the use of this test.

New studies of Zulliger with depressive subjects and other psychopathologies still need to be performed, as well as using the R-optimized application mode, avoiding the limitations of our study regarding sample, which was small and not paired by the level of education. Other factors should be considered in future research, such as the application of the tests in both clinical and non-clinical groups, at the same time and with the same purpose, contrary to what was possible in our study that used a database, although modeled. Modeling contributes to studies; however, they limit data generalization, since they do not reproduce exactly the same situation. Moreover, the modeling in this case matched the average of responses between the two groups, but these were not equivalent to the instructions received. The non-clinical group spontaneously produced that number of responses, which naturally marks a difference between the groups.

Finally, the validity and usefulness of the instruments must be constantly verified, which is not simple, given the multiplicity of variables involved in data collection and the infinite peculiarities of the sample participants. This makes the search for better ways of understanding people unceasing, so as to help them in the best possible way for their well-being.

\section{References}

American Psychiatric Association. (2014). Manual diagnóstico e estatístico de transtornos mentais: DSM-5 [Diagnostic and statistical manual of mental disorders: DSM-5] (M. I. C. Nascimento, Trans., 5th ed.). Porto Alegre, RS: Artmed.

Baptista, M. N. (2012). Manual técnico da Escala Baptista de Depressão em Adultos (EBADEP-A) [Escala Baptista de DepressãoTechnical Manual]. São Paulo, SP: Vetor. 
Beard, C., Millner, A. J., Forgeard, M. J. C., Fried, E. I., Hsu, K. J., Treadway, M. T., ... Björgvinsson, T. (2016). Network analysis of depression and anxiety symptom relationships in a psychiatric sample. Psychological Medicine, 46(16), 3359-3369. doi:10.1017/ S0033291716002300

Beck, A. T., Rush, A. J., Shaw, B. F., \& Emery, G. (1997). Terapia cognitiva da depressão [Cognitive depression therapy] (S. Costa, Trans.). Porto Alegre, RS: Artes Médicas.

Brinkmann, H. (1998). Proposición de parámetros para el Teste Zulliger [Parameter Proposition for the Zulliger Test]. Revista Chilena de Psicología, 19(2), 43-48. Retrieved from http://www2.udec.cl/ hbrinkma/articulo_z.pdf

Durisko, Z., Mulsant, B. H., \& Andrews, P. W. (2015). An adaptationist perspective on the etiology of depression. Journal of Affective Disorders, 172, 315-323. doi:10.1016/j.jad.2014.09.032

Exner, J. E., \& Sendín, C. (1999). Manual de interpretação do Rorschach para o sistema compreensivo [Rorschach interpretation manual for the comprehensive system] (L. Y. Massuh, Trans.). São Paulo, SP: Casa do Psicólogo.

Franco, R. R. C., \& Villemor-Amaral, A. E. (2012). O Zulliger e as Constelações do Rorschach no Sistema Compreensivo [Zulliger and Constellations of the Rorschach applied in System-Comprehensive]. Avaliação Psicológica, 11(1), 141-152. Retrieved from http://pepsic.bvsalud.org/scielo. php?script=sci_arttext\&pid=S167704712012000100013

Fried, E. I., \& Nesse, R. M. (2015). Depression is not a consistent syndrome: An investigation of unique symptom patterns in the STAR*D study. Journal of Affective Disorders, 172, 96-102. doi:10.1016/j.jad.2014.10.010

Goldberg, D. (2011). The Heterogeneity of "major depression". World Psychiatry, 10(3), 226-228. doi: 10.1002/j.2051-5545.2011.tb00061.x

Graceffo, R. A., Mihura, J. L., \& Meyer, G. J. (2014). A meta-analysis of an implicit measure of personality functioning: The Mutuality of Autonomy Scale. Journal of Personality Assessment, 96(6), 581-595. doi:10.1080/00223891.2014.919299

Grazziotin, J. B. D., \& Scortegagna, S. A. (2016a). Revisão de pesquisas brasileiras sobre o Teste de Zulliger publicadas em artigos [Literature review of Brazilian research about the Zulliger Z Test]. Avaliação Psicológica, 15(2), 227-235. Retrieved from

Grazziotin, J. B. D., \& Scortegagna, S. A. (2016b). Mediação no Zulliger: Evidências de validade em amostra de não pacientes [Mediation in Zulliger: Evidence of validity in sample of not patients]. Psico-USF, 21(1), 63-72. doi:10.1590/1413-82712016210106
Hosseininasab, A., Meyer, G. J., Viglione, D. J., Mihura, J. L., Berant, E., Resende, A. C., ... Mohammadi, M. R. (2019). The effect of CS administration or an R-Optimized alternative on R-PAS Variables: A meta-analysis of findings from six studies. Journal of Personality Assessment, 101(2), 199-212. doi:10.1080/ 00223891.2017.1393430. http://pepsic.bvsalud.org/scielo. php?script=sci_arttext\&pid=S1677-04712016000200012

Klein, M. (1948). Contributions to psycho-analysis. London, United Kingdom: Hogart.

Lichtenberg, P., \& Belmaker, R. H. (2010). Subtyping major depressive disorder. Psychotherapy and Psychosomatics, 79(3), 131-135. doi:10.1159/00028695

Mahmood, Z. (1990). The Zulliger test: Its past and future. British Journal of Projective Psychology, 35(2), 2-16.

Mattlar, C. E., Sandahl, C., Lindberg, S., Lehtinen, V., Carlsson, A., Vesala, P., \& Mahmood, Z. (1990). Methodological issues associated with the application of the comprehensive system when analysing the Zulliger, and the structural resemblance between the Zulliger and the Rorschach. British Journal of Projective Psychology, 35(2), 17-27.

Meyer, G. J., Hosseininasab, A., Viglione, D. J., Mihura, J. L., Berant, E., Resende, A. C., \& Reese, J. (2020). The effect of CS administration or an R-Optimized alternative on potential projective material in Rorschach responses from six studies and a meta-analysis of their findings. Journal of Personality Assessment, 102(1), 135-146. doi: 10.1080/00223891.2018.1492926

Meyer, G. J., Viglione, D. J., Mihura, J. L., Erard, R. E., \& Erdberg, R. (2017). Rorschach sistema de avaliação por desempenho manual de aplicação codificação e interpretação e manual técnico [Rorschach assessment system by performance manual application coding and interpretation and technical manual] (D. R. Silva \& F. K. Miguel, Trans.). São Paulo, SP: Hogrefe.

Mihura, J. L. (2012). The necessity of multiple test methods in conducting assessments: The role of the Rorschach and self-report. Psychological Injury and Law, 5(2), 97-106. doi:10.1007/s12207-012-9132-9

Mihura, J. L., \& Graceffo, R. A. (2014). Multimethod assessment and treatment planning. In C. J. Hopwood \& R. F. Bornstein (Eds.), Multimethod clinical assessment (pp. 285-318). New York, NY: Guilford.

Mihura, J. L., Meyer, G. J., Dumitrascu, N., \& Bombel, G. (2013). The validity of individual Rorschach variables: Systematic reviews and meta-analyses of the comprehensive system. Psychological Bulletin, 139(3), 548-605. doi:10.1037/a0029406 
Morey, L. C., \& McCredie, M. N. (2019). Convergence between Rorschach and self-report: A new look at some old questions. Journal of Clinical Psychology, 75(1), 202-220. doi:10.1002/jclp.22701

Rivera Carpio, S., \& Cubas Lugón, M. (2011). Validación del sistema comprehensivo de Exner en el test de Zulliger [Validation of the Exner comprehensive system in the Zulliger test]. Persona, (14), 145-158. Retrieved from http://revistas.ulima.edu.pe/index.php/Persona/article/ view/256/243

Shaffer, T. W., Erdberg, P., \& Haroian, J. (2007). Rorschach Comprehensive System data for a sample of 283 adult nonpatients from de United States. Journal of Personality Assessment, 89(Suppl. 1), S159-S165. doi:10.1080/00223890701583572

Vaz, C. E., \& Alchieri, J. C. (2016). Z-teste: Coletivo e individual: Técnica de Zulliger [Z-test: Collective and individual: Zulliger technique]. São Paulo, SP: Hogrefe.

Viglione, D. J., Meyer, G., Jordan, R. J., Converse, G. L., Evans, J., MacDermott, D., \& Moore, R. (2015). Developing an alternative Rorschach administration method to optimize the number of responses and enhance clinical inferences. Clinical Psychology and Psychotherapy, 22(6), 546-558. doi:10.1002/cpp.1913

Villemor-Amaral, A. E., \& Machado, M. A. S. (2011). Indicadores de depressão do Zulliger no Sistema Compreensivo (ZSC) [The depression index in the Zulliger Comprehensive System (ZSC)]. Paidéia (Ribeirão Preto), 21(48), 21-27. doi:10.1590/S0103- 863X2011000100004

Villemor-Amaral, A. E., \& Primi, R. (2009). Teste de Zulliger no sistema Compreensivo ZSC: Forma individual [Zulliger test in Comprehensive ZSC system]. São Paulo, SP: Casa do Psicólogo.

World Health Organization. (2017). Depression. Retrieved from $\mathrm{http} / /$ www.who.int/mediacentre/factsheets/fs369/en/

Zdunic, A. L. (1999). El Teste de Zulliger en la evaluación de personal: Aportes del Sistema Comprehensivo de Exner [The Zulliger Test in personnel evaluation: Contributions from the Comprehensive System of Exner]. Buenos Aires, Argentina: Paidós.

Zulliger, H., \& Salomon, F. (1970). El test Z - un test individual y colectivo [The test Z-an individual and collective test]. Buenos Aires, Argentina: Kapelusz.
André Pereira Gonçalves is master in psychology from Universidade São Francisco, Campinas-SP, Brazil.

Anna Elisa de Villemor-Amaral is a professor at the graduation program in Psychology of the Universidade São Francisco, Campinas-SP, Brazil.

\section{Authors' Contribution:}

All authors made substantial contributions to the conception and design of this study, to data analysis and interpretation, and to the manuscript revision and approval of the final version. All the authors assume public responsability for content of the manuscript.

Received: Oct. 15, 2018

1st Revision: Dec. 10, 2018

2nd Revision: Feb. 13, 2019

Approved: Mar. 26, 2019

How to cite this article:

Gonçalves, A. P., \& Villemor-Amaral, A. E. (2020). Zulliger R-Optimized in the evaluation of depressive characteristics. Paidéia (Ribeirão Preto), 30, e3023.doi:https://doi.org/10.1590/1982-4327e3023 